\title{
The Policy Context of International Crimes
}

\section{Citation}

Kelman, Herbert Chanoch. 2009. "The policy context of international crimes." In System criminality in international law, ed. A. Nollkaemper and H. van der Wilt, 26-41. Cambridge, UK: Cambridge University Press.

\section{Published Version}

doi:10.1017/CB09780511596650.003

\section{Permanent link}

http://nrs.harvard.edu/urn-3:HUL.InstRepos:11482677

\section{Terms of Use}

This article was downloaded from Harvard University's DASH repository, and is made available under the terms and conditions applicable to Other Posted Material, as set forth at http:// nrs.harvard.edu/urn-3:HUL.InstRepos:dash.current.terms-of-use\#LAA

\section{Share Your Story}

The Harvard community has made this article openly available.

Please share how this access benefits you. Submit a story.

Accessibility 


\section{The Policy Context of International Crimes}

\section{Herbert C. Kelman*}

Genocide, mass killing, torture, ethnic cleansing, and other gross violations of human rights are defined as war crimes or crimes against humanity under international law. To develop an adequate explanation of such actions, which is the task of social psychology, and an adequate legal response to them, which is the task of international law, requires going beyond the characteristics of individual perpetrators or even of the situations in which these practices take place. It requires close examination of the political system and of the policy process in which these actions are embedded and that provide the larger context for them.

\section{Crimes of obedience}

As a first step in this examination, we must define the special nature of the crimes under consideration. Some instances of such crimes may well constitute "ordinary" crimesthat is, crimes committed in violation of the expectations and instructions of authority. Participation in massacre, torture, or ethnic cleansing would be an ordinary crime in this sense if it were carried out by individual perpetrators on their own initiative and in

\footnotetext{
* Richard Clarke Cabot Professor of Social Ethics, Emeritus, Harvard University, USA. The paper draws
} extensively on two earlier publications: HC Kelman, 'The Social Context of Torture: Policy Process and Authority Structure' in RD Crelinsten and AP Schmid (eds), The Politics of Pain: Torturers and their Masters (1993); HC Kelman, ‘The Policy Context of Torture: A Social-Psychological Analysis’ (2005) 87(857) International Review of the Red Cross 123. 
disregard of the policies and orders of the authorities under which they function. Even a crime committed in the context of an authorized activity—such as a military operation or interrogation of prisoners—could be treated as an ordinary crime if the perpetrator went beyond legally permissible limits: if, for example, a soldier on a reconnaissance mission indiscriminately shot civilians, or if an interrogator used means of pressure in excess of what the rules permitted.

The essence of international crimes, such as war crimes and crimes against humanity, however, is that they are generally not ordinary crimes, but crimes of obedience: crimes that take place, not in opposition to the authorities, but under explicit instructions from the authorities to engage in these acts, or in an environment in which such acts are implicitly sponsored, expected, or at least tolerated by the authorities. Lee Hamilton and I have defined a crime of obedience as 'an act performed in response to orders from authority that is considered illegal or immoral by the larger community'. ${ }^{1}$ Torture provides a clear example of a crime of obedience: It is considered illegal and immoral by the international community; it is a crime under the U.N. Convention against Torture of $1984^{2}$ and other relevant international frameworks; and it is similarly defined in the national legal codes of many of the U.N.'s member states. Yet it is the authorities of these

\footnotetext{
${ }^{1}$ H.C. Kelman and V.L. Hamilton, Crimes of Obedience: Toward a Social Psychology of Authority and Responsibility (1989) 46.

${ }^{2}$ JH Burgers and H Danelius, The United Nations Convention against Torture: A Handbook on the Convention against Torture and Other Cruel, Inhuman or Degrading Treatment or Punishment (1988) $177-178$.
} 
very states that often order, encourage, or tolerate systematic policies or sporadic acts of torture.

When does an ordinary crime become a crime of obedience? It is often the case-in acts of torture as much as in massacre and other gross violations of human rights-that the perpetrators engage in the action willingly, enthusiastically, and with varying degrees of innovation. But 'the fact that a criminal action serves various personal motives or is carried out with a high degree of initiative and personal involvement does not necessarily remove it from the category of crimes of obedience, ${ }^{3}$ as long as the action is supported by the authority structure: as long as the perpetrators believe and have good reason to believe that the action is authorized, expected, at least tolerated, and probably approved by the authorities - that it conforms with official policy and reflects what their superiors would want them to do. To be sure, those who commit these crimes with enthusiasm and initiative are more culpable, from a legal and moral point of view, than those who commit them reluctantly in response to explicit orders. However, whether the action is caused or merely justified by explicit or implicit orders from superiors, it can be described as a crime of obedience, on the presumption that it would not have taken place without authorization.

Recognizing these actions as crimes of obedience immediately directs our attention to the other side of the coin: to the crimes of authority that invariably accompany crimes of

\footnotetext{
${ }^{3}$ HC Kelman and VL Hamilton, Crimes of Obedience: Toward a Social Psychology of Authority and Responsibility (1989) 50.
} 
obedience. For every subordinate who performs criminal acts under official orders or with the encouragement or toleration of the authorities, there is a superior-or typically an entire hierarchy of superiors - who issue the orders and who formulate the policies that require or permit these acts. Higher-level superiors may in fact not have issued specific orders to engage in these criminal acts, but they are the ones who formulate the policies, create the atmosphere, and establish the framework within which officials at intermediate levels of the hierarchy translate general policy directives into specific orders and actions on the ground.

The fact that crimes of obedience take place within a hierarchical structure makes it especially difficult to pinpoint responsibility for them. Subordinates deny responsibility by reference to superior orders. Superiors are often able to deny responsibility because they are various steps removed from the actions themselves and can claim that the initiative was taken at a lower level or that their instructions were misunderstood. The top leadership is protected by the difficulty in establishing causal links between the general atmosphere and policy directives they convey and the practices designed and carried out at lower levels of the hierarchy. The issue of assignment of responsibility in such situations is a central theme of the work reported in Crimes of Obedience, ${ }^{4}$ which began with a national survey of the U.S. population on public reactions to the conviction of Lt.

\footnotetext{
${ }^{4}$ HC Kelman and VL Hamilton, Crimes of Obedience: Toward a Social Psychology of Authority and Responsibility (1989).
} 
William Calley for the My Lai massacre in Vietnam ${ }^{5}$ - a prime example of what I have called sanctioned massacres. ${ }^{6}$

The important question in determining responsibility is not "who is responsible?" - the actor or the authority_-but "who is responsible for what?” When the question is framed that way, it becomes clear that both ought to be held responsible. The actors themselves are properly held responsible for the actions they perform and the harm they cause, even if they are acting under superior orders. Since the adoption of the Nuremberg Principles after World War II, which have been incorporated into the military codes of all Western states, superior orders cannot be used as an absolute defense for criminal actions on the part of subordinates. The U.N. Convention against Torture specifically applies this principle to torturers when it states that 'an order from a superior officer or a public authority may not be invoked as a justification of torture. ${ }^{7}$ Subordinates have the obligation to evaluate the legality of orders and to disobey those orders that they know or should have known to be illegal.

\footnotetext{
${ }^{5}$ HC Kelman and L Hamilton Lawrence, 'Assignment of Responsibility in the Case of Lt Calley: Preliminary Report on a National Survey’ (1972) 28(1) Journal of Social Issues; HC Kelman and VL Hamilton, ‘Availability for Violence: A Study of US Public Reactions to the Trial of Lt Calley’ in JD BenDak (ed), The Future of Collective Violence: Societal and Intersocietal Perspectives (1974).

${ }^{6}$ HC Kelman, 'Violence without Moral Restraint: Reflections on the Dehumanization of Victims and Victimizers’' (1973) 29(4) Journal of Social Issues.

${ }^{7}$ JH Burgers and H Danelius, The United Nations Convention against Torture: A Handbook on the Convention against Torture and Other Cruel, Inhuman or Degrading Treatment or Punishment (1988) 178.
} 
Superiors, for their part, have the obligation to consider the consequences of the policies they set and to oversee the ways in which those policies are translated into specific orders and actions as they move down the ladder. The authorities' obligation of oversight makes the defense of ignorance of or lack of control over the actions of subordinates generally unacceptable, since they are expected to know and to control what their subordinates are doing. Of course, more often than not, massacre and torture do not result from negligence at the top, but from deliberate policy—or perhaps deliberate inattention at the top to the way in which policy is carried out below.

\section{The policy context}

Conceptualizing international crimes as crimes of obedience implies that they must be understood in the context of the policy process that gives rise to them and of the authority structure within which this policy is carried out. To concretize my analysis of the policy context of international crimes, I focus specifically on torture as a case in point. The same logic applies, however, to sanctioned massacres, to systematic expulsions, and to other war crimes and crimes against humanity.

The issue of torture-particularly in situations of armed conflict or in the fight against terrorism—received widespread international attention when the abuses of Iraqi prisoners by U.S. soldiers at Abu Ghraib came to light in the spring of 2004. Torture, of course, is not a peculiarly American phenomenon. Unfortunately, it is widely practiced in many parts of the world; moreover, it is endemic to autocratic states and is far less prevalent in 
democratic ones. Abu Ghraib serves as a reminder, however, that even democratic states may resort to torture when a particular set of social conditions is in place, and it illustrates the policy context in which the practice of torture is embedded.

In the case of Abu Ghraib, the findings of the investigative reporter, Seymour Hersh ${ }^{8}$ the same man, incidentally, who broke the story of the My Lai massacre and its coverup ${ }^{9}$ - make it evident that the abuses were part of a systematic process. They took place in the context of interrogation and were apparently designed to 'soften up' prisoners for questioning by intelligence officers. No doubt, some of the perpetrators engaged in these actions with a greater degree of initiative and sadistic enjoyment than others, but they were operating in an atmosphere of pressure to produce intelligence information from prisoners presumed to be guilty. Whether or not some of the specific abuses and acts of torture were directly ordered, indications are that they were expected, condoned, and encouraged by higher officers. Commanding officers along the different tiers of the hierarchy have been accused, at the least, of exercising insufficient oversight of the conditions of detention and procedures of interrogation that prevailed in Abu Ghraib and other military prisons for suspected terrorists.

In the months following the exposure of the Abu Ghraib abuses, it became increasingly evident that the treatment of the Abu Ghraib prisoners was not an isolated occurrence,

\footnotetext{
${ }^{8}$ S Hersh, 'Torture at Abu Ghraib’ (2004) 80(11) The New Yorker; S Hersh, 'Chain of Command' (2004) 80(12) The New Yorker.

${ }^{9}$ S Hersh, My Lai 4: A Report on the Massacre and its Aftermath (1970); S Hersh, Cover-Up (1972).
} 
nor was it simply the product of decisions and actions (or inaction) at the local level. Similar patterns of abuse, linked to aggressive interrogation techniques, occurred in prisons elsewhere in Iraq, and—going back to 2002—in Afghanistan and Guantánamo Bay. Numerous documents show that the techniques and practices revealed in Abu Ghraib had "migrated” from Guantánamo and Afghanistan and that they were authorized or justified at various points by high-ranking officials in the Pentagon and the White House. ${ }^{10}$ For example, memos circulating in upper echelons of the administration authorized harsh interrogation techniques; defined torture so narrowly that many forms of painful, debilitating, and degrading treatment became permissible; and suggested that the Geneva Conventions did not apply to 'unlawful combatants' ${ }^{11}$ The mistreatment of prisoners revealed by the various reports, particularly given the context in which it occurred, has all the earmarks of physical and mental torture. And, indeed, the accounts presented in these reports are highly reminiscent of what is known about the conditions that have given rise to torture so often in the past anywhere in the world.

While I look to the policy process and the authority structure to identify the major determinants of acts of torture as well as the major correctives against these practices, I do not minimize the role of individual and cultural differences. With respect to individual differences, I am sure there is a certain degree of self-selection of individuals who

\footnotetext{
${ }^{10}$ M Danner, Torture and Truth: America, Abu Ghraib, and the War on Terror (2004); S Strasser, The Abu Ghraib Investigation: The Official Independent Panel and Pentagon Reports on the Shocking Prisoner Abuse in Iraq (2004).

${ }^{11}$ cf K Zernike, 'Newly Released Reports Show Early Concern on Prison Abuse’ New York Times (6 January 2005).
} 
gravitate to the role of torturer. Moreover, those operating within the role vary in the amount of enthusiasm, diligence, and innovativeness that they bring to the task. No doubt differences in personality and background play an important part in determining who becomes a torturer and who acts out that role eagerly and with evident enjoyment. But a focus on structural factors helps us understand why many, perhaps most, torturers are not sadists but ordinary people, doing what they understand to be their jobs. I might add that individual differences in readiness to engage in torture may be related as much to people's orientation toward authority as they are to their propensity toward aggression or their sense of compassion. ${ }^{12}$

Cultural differences—-particularly differences in political culture—no doubt also play an important role. Thus, Berto Jongman ${ }^{13}$ showed that human rights violations, including torture, were much more likely to occur in non-democratic than in democratic societies (84 per cent v. 25 per cent); and in countries at low levels than in those at high levels of development (84 per cent v. 31 per cent). Democratic countries are less likely to practice torture precisely because of the nature of their policy process and authority structure. But torture does occur even in highly developed democratic societies, usually in the context of counter-terrorist activities or armed conflict, as the experiences of Guantánamo Bay and Abu Ghraib well illustrate. There are social conditions under which democratic cultures that ordinarily respect human rights may sanction torture, just as there are social

\footnotetext{
${ }^{12}$ HC Kelman and VL Hamilton, Crimes of Obedience: Toward a Social Psychology of Authority and Responsibility (1989) chs 11 and 12.

${ }^{13}$ B Jongman, 'Why Some States Kill and Torture while Others Do Not' (1991) 3(1) PLOOM Newsletter.
} 
conditions under which ordinary, decent individuals may be induced to take part in it. Thus, while individual and cultural factors are important determinants of torture, they operate in interaction with the policy process and the authority structure that ultimately give rise to the practice.

How can we account for torture and its characteristic manifestations within this framework - both at the macro-level and at the micro-level? At the macro-level, what are the structural and situational conditions that encourage and enable the relevant authorities to use torture as an instrument of policy? At the micro-level, what are the conditions that encourage and enable individuals and organizations to participate when asked to implement this policy?

\section{The use of torture as an instrument of policy}

Torture has been practiced by collective actors other than states, such as guerrilla groups or liberation movements, but it has been analyzed primarily as a phenomenon linked to the state. The emergence or reemergence of torture as an instrument of policy in the twentieth century is directly related to the nature of the modern state. In particular, as Edward Peters ${ }^{14}$ argues in his historical study, torture arises from the combination of two features of the modern state: its vast power and its enormous vulnerability to state enemies, internal and external. The power of the modern state rests in the extent to which it affects all aspects of the life of its citizens and the resources that it can mobilize to control its population. The vulnerability of the modern state stems from the high degree

${ }^{14}$ E Peters, Torture (1985). 
of interdependence of the political, economic, and social institutions required to run a modern society and the resulting ease with which social order can disintegrate and the political authorities can lose control when their legitimacy declines in the eyes of their population or when they confront terrorism and insurgency.

The conditions conducive to the rise of torture as an instrument of state policy are the authorities' perception of an active threat to the security of the state from internal and external sources; the availability of a security apparatus, which enables the authorities to use the vast power at their disposal to counter that threat by repressive means; and the presence within the society of groups defined as enemies of or potential threats to the state (see Table 1).

Table 1: The policy context of torture

\begin{tabular}{|c|c|c|}
\hline CONDITIONS CONDUCIVE & SOCIAL PROCESSES & ACILITATING TORTURE \\
\hline $\begin{array}{c}\text { AS AN INSTRUMENT OF } \\
\text { POLICY }\end{array}$ & At Level of Policy Formation & At Level of Implementation \\
\hline $\begin{array}{l}\text { Perception of a Security } \\
\text { Threat }\end{array}$ & $\begin{array}{l}\text { Justification of a policy of } \\
\text { torture }\end{array}$ & Authorization of acts of torture \\
\hline $\begin{array}{l}\text { Existence of a Security } \\
\text { Apparatus }\end{array}$ & $\begin{array}{l}\text { Development of professional } \\
\text { torture cadres }\end{array}$ & $\begin{array}{l}\text { Routinization of torture } \\
\text { practices }\end{array}$ \\
\hline $\begin{array}{l}\text { Presence of Groups Defined } \\
\text { as Enemies of the State }\end{array}$ & $\begin{array}{l}\text { Exclusion of target groups } \\
\text { from protection of the state }\end{array}$ & $\begin{array}{l}\text { Dehumanization of targets of } \\
\text { torture }\end{array}$ \\
\hline
\end{tabular}

Source: HC Kelman, ‘The Policy Context of Torture: A Social-Psychological Analysis’ (2005) 87(857) International Review of the Red Cross 128. Reprinted by permission of the publisher, the International Committee of the Red Cross. 
The recourse to repression is particularly likely in situations in which opposition represents a challenge to the legitimacy of those in power and thus a fundamental threat to their continued ability to maintain power, such as states in which the rulers' legitimacy rests on a unitary, unchangeable ideology (political or religious), or states run by a ruling clique with an extremely narrow population base (in socioeconomic and/or ethnic terms) but with the support of military forces. However, torture may also be used, sporadically or sometimes systematically, by democratic regimes that find themselves in charge of ethnically distinct populations or subpopulations that do not accept their rule-such as Israel in the occupied territories or Britain in Northern Ireland.

When state authorities resort to torture, they can often point to a history of violence directed against the state: in the form of insurgency, guerrilla operations, or terrorist acts. To be sure, torture may at times be applied to individuals whose only crime is political or religious dissent, or even mere membership in a religious or ethnic community that does not fit into the ruling group's scheme of things. Even where there is a history of violence, the apparatus of torture is not particularly discriminating in the selection of its victims. Individuals who have not participated in violent action at all may be singled out for torture for any number of reasons: because they are members of or supporters of political opposition groups; because they belong to an ethnic, religious, or even professional category—as happened in Argentina during its "dirty war" ${ }^{15}$-that is generally suspect; because they are deemed guilty by association (perhaps because they are related to suspects); or simply because they are picked up at random or on the basis of mistaken

\footnotetext{
${ }^{15}$ See A Elon, 'A Letter from Argentina’ (21 July 1986) The New Yorker.
} 
identity. Still, the occurrence or perceived threat of violence against the state is central to the rationale for a policy of torture. ${ }^{16}$

Given the centrality of the threat of violence in the rationale for a policy of torture in modern times, it is not surprising that torture is particularly likely to occur in the context of war or armed conflict. Although my analysis so far has focused on torture within the state, aimed at repressing domestic groups or populations whom the authorities perceive as internal threats to the security of the state or as agents and allies of external enemies of the state, it is equally applicable to situations of war and occupation, in which torture may be used against members or suspected supporters of the enemy camp. The use of torture in war situations—often directed at civilians, as well as at military personnel—has become more probable as war has moved from the classical clash between organized armed forces to a clash between whole populations, in which civilian groups are often specifically targeted. ${ }^{17}$ Torture in this context may be used as part of a state's policy of control and repression of the population and as an instrument of interrogation or psychological warfare. The conditions conducive to the use of torture in situations of armed conflict are identical to those outlined in the table. Once again, democratic regimes are not immune to the use of torture under these conditions, as the U.S. actions in Afghanistan and Iraq so clearly illustrate.

\footnotetext{
${ }^{16}$ WS Heinz, 'The Military, Torture and Human Rights: Experiences from Argentina, Brazil, Chile and Uruguay' in RD Crelinsten and AP Schmid (eds), The Politics of Pain: Torturers and their Masters (1993).

${ }^{17}$ M Shaw, War and Genocide: Organized Killing in Modern Society (2003).
} 


\section{Social processes facilitating a policy of torture}

At the level of policy formation, there are three important points at which the perceived threat to the security of the state provides the rationale for a policy of torture, and the power of the state enables it to implement that policy: in establishing the purpose and justification of the torture, in recruiting the agents or perpetrators of the torture, and in defining the targets of the torture (see table).

First, the essential justification of torture, as has already been proposed, is the protection of the state against internal and external threats to its security-which often means the maintenance in power of those more or less narrow elements of the population that have gained control of the state apparatus. The practice of torture is justified by reference to the particular doctrine of the state's legitimization: maintaining law and order or stability, or the rule of "the people" whom the state claims to embody, or the rule of God, or the survival of Western civilization, or the integrity of national institutions. In war situations, of course, the justification for taking up arms, generally couched in terms of defense against threats to national security and to the vital interests of the state, also covers whatever steps are deemed necessary-including torture-to achieve the military objectives.

Second, the agents of torture are defined as a professional force with a significant role in protecting the state against internal threats to its security. The power of the state allows it to mobilize the necessary resources to establish a torture apparatus. A central component 
of that mobilization process is the recruitment of a cadre of torture practitioners through the development of what is in effect an organized profession—a profession that is wholly owned by the state, that operates within the state's internal security framework, and that is dedicated to the service and protection of the state. Like other professionals, torturers undergo a rigorous process of professional training, socialization, and indoctrination to prepare them for their roles. ${ }^{18}$ Typically, this process includes torture resistance training, which acclimatizes them to cruelty. ${ }^{19}$ (In war situations, it might be noted here, acclimatization to violence and cruelty is a daily occurrence, requiring no specialized training.) Another element of the professionalization of torture is that it has become an international enterprise. Torturers from different parts of the world come together in international meetings in which they share information about training procedures and torture techniques. The similarity in the techniques of torture used across the world is startling. Some of this is probably due to independent discovery and innovation, but much of it can be credited to professional exchange.

Third, the targets of torture are defined as enemies of the state who constitute serious threats to the state's security and survival. For that, as well as for other reasons, such as their ethnicity or ideology, they are placed outside the protection of the state. In the

\footnotetext{
${ }^{18}$ H Radtke, 'Torture as an Illegal Means of Control' in F Bockle and J Pohier (eds), The Death Penalty and Torture (1979); JT Gibson, 'Factors Contributing to the Creation of Torture’ in P Suefeld (ed), Psychology and Torture (1990).

${ }^{19}$ H Radtke, 'Torture as an Illegal Means of Control' in F Bockle and J Pohier (eds), The Death Penalty and Torture (1979); RD Crelinsten, 'In Their Own Words: The World of the Torturer' in RD Crelinsten and AP Schmid (eds), The Politics of Pain: Torturers and their Masters (1993).
} 
modern state, individual rights in effect derive from the state. Thus, to be excluded from the state — to be denied the rights of citizenship—is tantamount to becoming a non-person vulnerable to arbitrary treatment, to torture, and ultimately to extermination. Targets of torture in the context of armed conflict are, by definition, placed in the category of enemies, who are not entitled to the protection of the state. In principle, enemy combatants and civilian populations are protected against torture and other violations of their human rights by the Geneva Conventions. ${ }^{20}$ In practice, people categorized as enemies in a war situation are vulnerable to being targeted for torture.

\section{Social processes facilitating participation in torture}

The three points at which the security concerns and power of the state contribute to a policy of torture at the macro-level-i.e., the justification for torture, the agents of torture, and the targets of torture — can be linked to three social processes that facilitate participation in torture at the micro-level: the processes of authorization, routinization, and dehumanization, which I distinguished in my earlier analysis of sanctioned massacres and other crimes of obedience. ${ }^{21}$ The justification of torture as a means of protecting the state against threats to its security helps to authorize the practice; the development of a

\footnotetext{
${ }^{20}$ Geneva Convention Relative to the Treatment of Prisoners of War (Geneva Convention III) (Geneva, 12 August 1949; 75 UNTS 135); Geneva Convention Relative to the Protection of Civilian Persons in Time of War (Geneva Convention IV) (Geneva, 12 August 1949; 75 UNTS 287).

${ }^{21}$ HC Kelman, 'Violence without Moral Restraint: Reflections on the Dehumanization of Victims and Victimizers' (1973) 29(4) Journal of Social Issues; HC Kelman and VL Hamilton, Crimes of Obedience: Toward a Social Psychology of Authority and Responsibility (1989).
} 
profession of torturers as part of the state's security apparatus helps to routinize the administration of torture; and the designation of the targets of torture as enemies of the state who are excluded from the state's protection helps to dehumanize the victims (see table, right-hand column).

In the analysis of sanctioned massacres I argued that, to understand participation in massacre or genocide, it is less important to explore the forces that push people into performing such violent acts than to explore those forces that contribute to the weakening of moral restraints against performing these acts—acts that people would normally find unacceptable. Within this framework, authorization helps to define the situation in a way that makes standard moral principles inapplicable: The individual is not acting as an independent moral agent and therefore feels absolved of the responsibility to make personal moral choices. Through routinization, the action becomes organized in a way that eliminates the opportunity to raise moral questions and make moral decisions: The action is divided among many individuals and sub-units of the organization; each individual carries out routine tasks without having to think of the overall product to which these tasks contribute; euphemisms further enable individuals to ignore the overall meaning of the tasks they are performing; altogether, the actions come to be seen as part of a normal job rather than participation in massacre or genocide. Finally, dehumanization of the victims makes it unnecessary for perpetrators to relate to them in moral terms, since it excludes the victims from the perpetrators' moral community. 
These three social processes apply to torturers as much as to participants in massacre or other crimes of obedience. In the case of torture, it is particularly clear that these processes are mediated to a significant degree by the torturers' relationship to the state.

The role of authorization is strengthened by the fact that torturers, typically, are not just acting within a hierarchy in which they are expected to obey-and have indeed been trained to obey without question ${ }^{22}$ - but they are participating in an action that represents a transcendent mission. They have come to share the view of the authorities that the task they are engaged in serves a higher purpose that transcends any moral scruples they might bring to the situation. They have come to see themselves as playing an important part in an effort to protect the state: to ensure its security and continued integrity, to maintain law and order, or to keep alive the fundamental values of the state that are being subjected to a merciless onslaught by ruthless enemies who are intent on destroying it. This view of the purpose of the torture project as part of a noble effort, in which the perpetrators are prepared to play their role despite any moral reservations and feelings of repugnance they might have, greatly enhances the legitimacy of the enterprise.

An additional element of the torture situation that contributes to its perceived legitimacy is the participation of medical professionals, who often play an active role by evaluating victims' physical capacity to go through the process, by making sure that the torture does

\footnotetext{
${ }^{22}$ JT Gibson, 'Factors Contributing to the Creation of Torture' in P Suedfeld (ed), Psychology and Torture (1990).
} 
not go beyond the point of causing the victim to die, and by performing other functions. ${ }^{23}$ Incidentally, the role of physicians in interrogations that are tantamount to torture has also been noted in the Abu Ghraib situation. ${ }^{24}$ Physicians have also played a role in developing torture techniques, including brainwashing and related psychological methods of torture. An extreme example of the role of physicians in legitimizing torture and the systematic killing of "undesirables" and enemies of the state is the case of the Nazi doctors, who helped to formulate the biomedical vision underlying the Nazi genocidal programs. $^{25}$

The justification of torture as a necessary means of ferreting out "the truth" also helps to surround it with an aura of legitimacy, as does the legal context in which it often takes place. One of the common uses of torture is as an adjunct to judicial proceedings, where it is designed to obtain evidence to be introduced into trials. This practice goes back to the early uses of torture - in the Roman period and in the Middle Ages_-as a central part of the process of producing a confession, which was deemed necessary to establish the guilt of the accused. ${ }^{26}$

\footnotetext{
${ }^{23}$ SV Faraone, 'Psychology’s Role in the Campaign to Abolish Torture: Can Individuals and Organizations Make a Difference?’ in P Suedfeld (ed), Psychology and Torture (1990); see also JM Arrigo, ‘A Utilitarian Argument against Torture Interrogation of Terrorists' (2004) 10(3) Science and Engineering Ethics.

${ }^{24}$ eg, MG Bloche and JH Marks, 'When Doctors Go to War' (2005) 29(11) The New England Journal of Medicine.

${ }^{25}$ RJ Lifton, The Nazi Doctors: Medical Killing and the Psychology of Genocide (1986).

${ }^{26}$ E Peters, Torture (1985).
} 
Routinization of torture is enhanced by the establishment of torturers as a professional group (as described in the previous section), which contributes to normalizing and ennobling their work. Torturers come to see themselves as performing a job, as doing their duty. It is a job that often involves hard work, that can lead to promotion and other rewards, that may offer opportunities to demonstrate innovativeness, that one can excel in and become expert in. Above all, it is a job that one can be proud of because it is perceived as a special profession that provides a significant service to the state and often carries with it membership in an elite corps. Although some torturers may seek out this occupation because of their sadistic inclinations, many are ordinary people who come to this work through a number of different routes.

The torture process itself also shows signs of considerable routinization. It usually involves a series of steps, clearly identified, and following each other in regular sequence. The different torture techniques, as well as the different torture chambers, are typically designated by special names, often with a euphemistic or ironic quality. These names are not so much designed to hide the reality of what is actually taking place as to give expression to a professional culture with its own rituals and language. ${ }^{27}$ The procedures used by torture organizations—including a variety of psychological techniques-are often quite sophisticated. All of this helps to give the work an aura of professionalism, which allows the torturer to perceive it, not as an act of cruelty against another human being, but as the routine application of specialized knowledge and skills.

\footnotetext{
${ }^{27}$ H Radtke, 'Torture as an Illegal Means of Control' in F Bockle and J Pohier (eds), The Death Penalty and Torture (1979).
} 
In dehumanization, too, the state is an important part of the equation. The exclusion of torture victims from the torturer's moral community goes back, in fact, to the early history of torture. In the Roman legal system, torture-as a means of obtaining confessions—-was originally applied only to slaves and foreigners, but not to citizens. ${ }^{28}$ In contemporary practice, as well, torture victims are or are treated as non-citizens. The main source of their dehumanization is their designation as enemies of the state who have placed themselves outside the moral community shared by the rest of the population. They are described as terrorists, insurgents, or dissidents who endanger the state and are bent on undermining law and order and destroying the community. The view of torture victims as non-citizens, who are not entitled to the protection of the state, was evident in interviews that Heinz ${ }^{29}$ conducted with "masters of torture" in Latin America: Once they identified guerrillas as Communists, they saw them as foreign agents and thus, in effect, “denaturalized.” Furthermore, torture increased when guerrillas began killing military officers and their families, because they came to be seen as not only outsiders, who are not entitled to the community's protection, but as dangerous elements, against whom the community had a right to protect itself.

A central assumption in the contemporary practice of torture-just as in the early days, when it was used as a systematic part of criminal legal procedures-is that the victims are

\footnotetext{
${ }^{28}$ E Peters, Torture (1985).

${ }^{29}$ WS Heinz, 'The Military, Torture and Human Rights: Experiences from Argentina, Brazil, Chile and Uruguay' in RD Crelinsten and AP Schmid (eds), The Politics of Pain: Torturers and their Masters (1993).
} 
guilty. The torture apparatus operates on the assumption that those who are brought in for torture are guerrillas, insurgents, or terrorists, who have committed and/or are about to commit dangerous crimes against the state. Thus, torture is designed only to punish the guilty, to warn their accomplices, and—most important—-to elicit the truth from them. Indeed, torture is often justified on the grounds that it is the only way to elicit information necessary for the protection of the state and its citizens—such as information about the identity and whereabouts of terrorist leaders or about planned terrorist operations—-that the torture victims are presumed to have in their possession.

A contributing factor to the dehumanization of torture victims is the fact that-even when they are citizens of the state that tortures them-they are often outside the ethnic or religious community of the torturers and of the dominant sector of the society. This has been the case, among many others, for Kurds in Iraq, for Bahais in Iran, for Palestinians in Kuwait and in the Israeli-occupied territories, for Irish Catholics in Northern Ireland, or for Bosnian Muslims in the former Yugoslavia. In many cases, the victims' ethnic or religious identity is itself the primary reason for their vulnerability to torture. In other cases, ethnic or religious identity is a factor in dissent or insurgency. In all cases, it facilitates exclusion and dehumanization, thus removing one of the constraints against torture and other serious violations of human rights. 


\section{Conclusion}

Using torture as the primary illustration, the present analysis suggests some of the conditions under which practices constituting international crimes can become instruments of state policy and the authority structure of the state is fully mobilized to implement that policy: the perception by state authorities that the security of the state is under severe threat-which, at the macro-level, serves to justify these practices and, at the micro-level, contributes to their authorization; the existence of an elaborate and powerful apparatus charged with protecting the security of the state-which, at the macro-level, provides the infrastructure for implementing such practices and, at the micro-level, contributes to their routinization; and the existence of groups within the state or under its control that are defined as enemies of the state-which, at the macro-level, excludes them from protection of the state and, at the micro-level, contributes to their dehumanization.

These conditions are endemic to the autocratic security state. Thus, torture and other gross violations of human rights are much less likely to take place in states governed with the consent of the governed, whose leaders and officials are accountable for their policies and actions. However, even Western democratic societies are not invulnerable to the conditions that tempt state authorities to adopt such practices as policy instruments and that enable them to implement policies that rely on these practices: the perception of fundamental threats to the security and integrity of the state; the existence of bureaucratic organizations charged with ensuring state security, staffed by professionally trained 
security specialists, and allowed to operate with greater secrecy and less accountability than is customary in democratic societies; and the presence of foreign, poorly integrated, or non-citizen elements within the population or under the state's control that can easily be seen as outside of the contract that obligates citizens and state to one another in a democratic polity. These conditions are particularly likely to arise in the context of armed conflict—whether civil or international—in which the threat to the state is readily personified in an internal or external enemy, bent on violence and destruction. The combination of these conditions can override the constraints and bypass the scrutiny, imposed by democratic values and institutions, that usually stand in the way of gross violations of human rights in democratic societies. These, then, are the conditions that must be addressed-wherever they manifest themselves—as we seek to develop approaches to enhancing accountability for system-generated international crimes, not only on the part of individuals at all levels of the system's hierarchy, but on the part of the system itself. 


\section{References}

JM Arrigo, ‘A Utilitarian Argument against Torture Interrogation of Terrorists’ (2004) 10(3) Science and Engineering Ethics 543-572.

MG Bloche and JH Marks, 'When Doctors Go to War' (2005) 29(11) The New England Journal of Medicine 3-6.

JH Burgers and $\mathrm{H}$ Danelius, The United Nations Convention against Torture: A Handbook on the Convention against Torture and Other Cruel, Inhuman or Degrading Treatment or Punishment (Dordrecht/Boston/London: Martinas Nijhoff, 1988).

RD Crelinsten, 'In Their Own Words: The World of the Torturer' in RD Crelinsten and AP Schmid (eds), The Politics of Pain: Torturers and their Masters (Leiden: COMT, University of Leiden, 1993) 39-72.

M Danner, Torture and Truth: America, Abu Ghraib, and the War on Terror (New York: New York Review Books, 2004).

A Elon, ‘A letter from Argentina’ (21 July 1986) The New Yorker 74-86.

SV Faraone, 'Psychology’s Role in the Campaign to Abolish Torture: Can Individuals and Organizations Make a Difference?' in P Suedfeld (ed), Psychology and Torture (New York: Hemisphere, 1990) 185-193.

JT Gibson, 'Factors Contributing to the Creation of Torture' in P Suedfeld (ed), Psychology and Torture (New York: Hemisphere, 1990) 77-88.

WS Heinz, 'The Military, Torture and Human Rights: Experiences from Argentina, Brazil, Chile and Uruguay' in RD Crelinsten and AP Schmid (eds), The Politics 
of Pain: Torturers and their Masters (Leiden: COMT, University of Leiden, 1993) 73-108.

S Hersh, My Lai 4: A Report on the Massacre and its Aftermath (New York: Vintage Books, 1970).

S Hersh, Cover-up (New York: Random House, 1972).

S Hersh, ‘Torture at Abu Ghraib’ (2004) 80(11) The New Yorker 42-47.

S Hersh, 'Chain of Command' (2004) 80(12) The New Yorker 38-43.

B Jongman, 'Why Some States Kill and Torture while Others Do Not (1991) 3(1) PLOOM Newsletter 8-11.

HC Kelman, 'Violence without Moral Restraint: Reflections on the Dehumanization of Victims and Victimizers' (1973) 29(4) Journal of Social Issues 25-61.

HC Kelman, 'The Social Context of Torture: Policy Process and Authority Structure’ in RD Crelinsten and AP Schmid (eds), The Politics of Pain: Torturers and their Masters (Leiden: COMT, University of Leiden, 1993) 21-38.

HC Kelman, 'The Policy Context of Torture: A Social-Psychological Analysis' (2005) 87(857) International Review of the Red Cross 123-134.

HC Kelman and VL Hamilton, 'Availability for Violence: A Study of U.S. Public Reactions to the Trial of Lt. Calley' in JD Ben-Dak (ed), The Future of Collective Violence: Societal and Intersocietal Perspectives (Lund: Studentlitteratur, 1974) $125-142$.

HC Kelman and VL Hamilton, Crimes of Obedience: Toward a Social Psychology of Authority and Responsibility (New Haven and London: Yale University Press, 1989). 
HC Kelman and L Hamilton Lawrence, 'Assignment of Responsibility in the Case of Lt. Calley: Preliminary Report on a National Survey’ (1972) 28(1) Journal of Social Issues 177-212.

RJ Lifton, The Nazi Doctors: Medical Killing and the Psychology of Genocide (New York: Basic Books, 1986).

E Peters, Torture (New York and London: Basil Blackwell, 1985).

H Radtke, 'Torture as an Illegal Means of Control' in F Bockle and J Pohier (eds), The Death Penalty and Torture (New York: Seabury Press, 1979) 3-15.

M Shaw, War and Genocide: Organized Killing in Modern Society (Cambridge, UK: Polity Press, 2003).

S Strasser, The Abu Ghraib Investigation: The Official Independent Panel and Pentagon Reports on the Shocking Prisoner Abuse in Iraq (New York: Public Affairs, 2004).

K Zernike, 'Newly Released Reports Show Early Concern on Prison Abuse’ (New York, 6 January 2005) New York Times A1 and A18. 